\title{
Accounts of Grains and Properties
}

Apart from the land and grain taxes, accounts of grains and properties also constitute a part of the excavated corpus of Tangut documents. Although most are in fragments, there is still new information to be extracted from these primary sources, which add to our existing understanding of Tangut society and economy.

\section{Accounts of Grains}

Grain accounts include those kept by officials in military supervisory districts and those by the unit of liliu. The former, found mostly on the layering page of sutra covers, are rarely complete. However, the liliu accounts are kept as single pages, with the beginning and end more or less intact and the amounts of grains in large numbers.

\subsection{Grain Accounts of the Military Supervisory Districts}

Grain accounts at military supervisory districts survive mostly as page fragments in the inner layer of sutra covers, such as Russian manuscripts Инв. No. 438, Инв. No. 441 and Инв. No. 723 (year of $\mathrm{Si}$ ). In these mostly incomplete accounts, the titles "military supervisory commission" or "imperial capital" are uniformly featured, suggesting that these grain accounts have to do with Tangut military affairs.

Grain account manuscript Инв. No. 438 is written in the cursive style on a $31.2 \times 3^{2} \mathrm{~cm}$ hemp cover paper, with the top and bottom pieces of paper stitched together into a single page. The Tangut writings are in lines 11 and 12.

Grain account manuscript Инв. No. 441 is written in the cursive style on a $31.6 \times 3^{2} \mathrm{~cm}$ hemp cover paper, with the top and bottom pieces stitched together into a single page. The Tangut writings are in lines 13 and 13 .

Grain account manuscript Инв. No. 723 (year of $S i$ ) is written in the cursive style on a $31.6 \times 30.8 \mathrm{~cm}$ hemp cover paper, likewise, with the top and bottom pieces stitched together into a single page. Each page features 12 lines of Tangut writings. While the top piece suffers more damages, written in lines 1 and 7 of the bottom piece are "Eleventh month in the Year of $S i$ " and "last month in the Year of $S i$," respectively. ${ }^{1}$

1 Russian Collection of Khara-Khoto Manuscripts 12, pp. 117, 118, 136. 


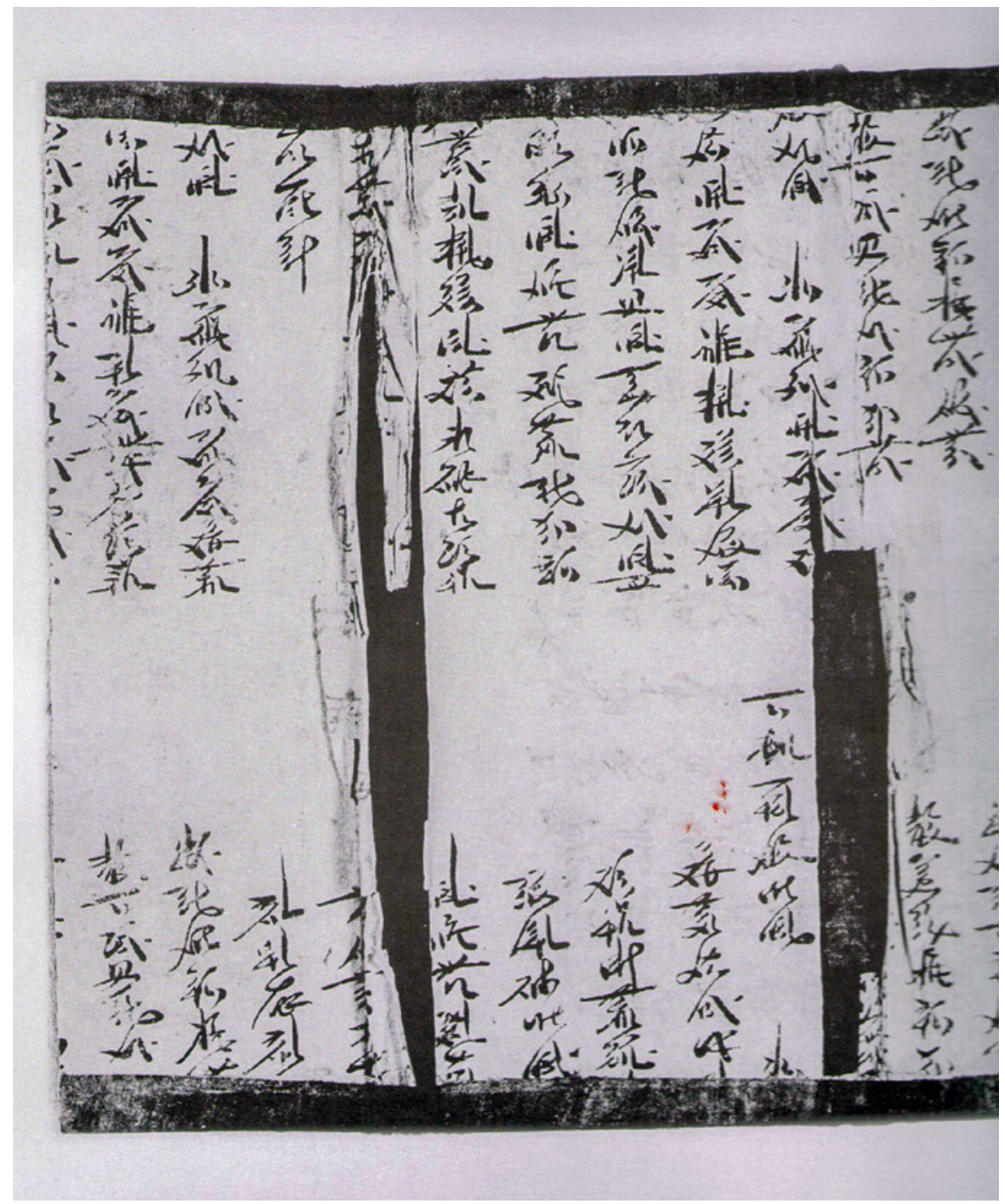

FIGURE 53 Инв. No. 438: Grain account

The content of the manuscript fragments is organised by itemised entries. Under the title of each item, the un-indented top begins with the Tangut characters 罗剩 (lit. one, liu). The numeral 'one' is straightforward and easy to understand. As for the second character, its generic meaning is 'item,' which extends to the use of the term 'military liu' as the basic unit of organization in the Tangut army. Since the latter is much more likely to be its meaning in this particular context, it is fair to assume that these grain accounts are kept by military divisions, with each liu as a single unit. Almost every entry features

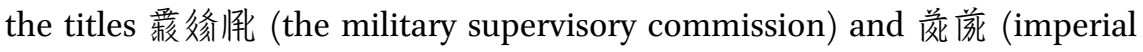




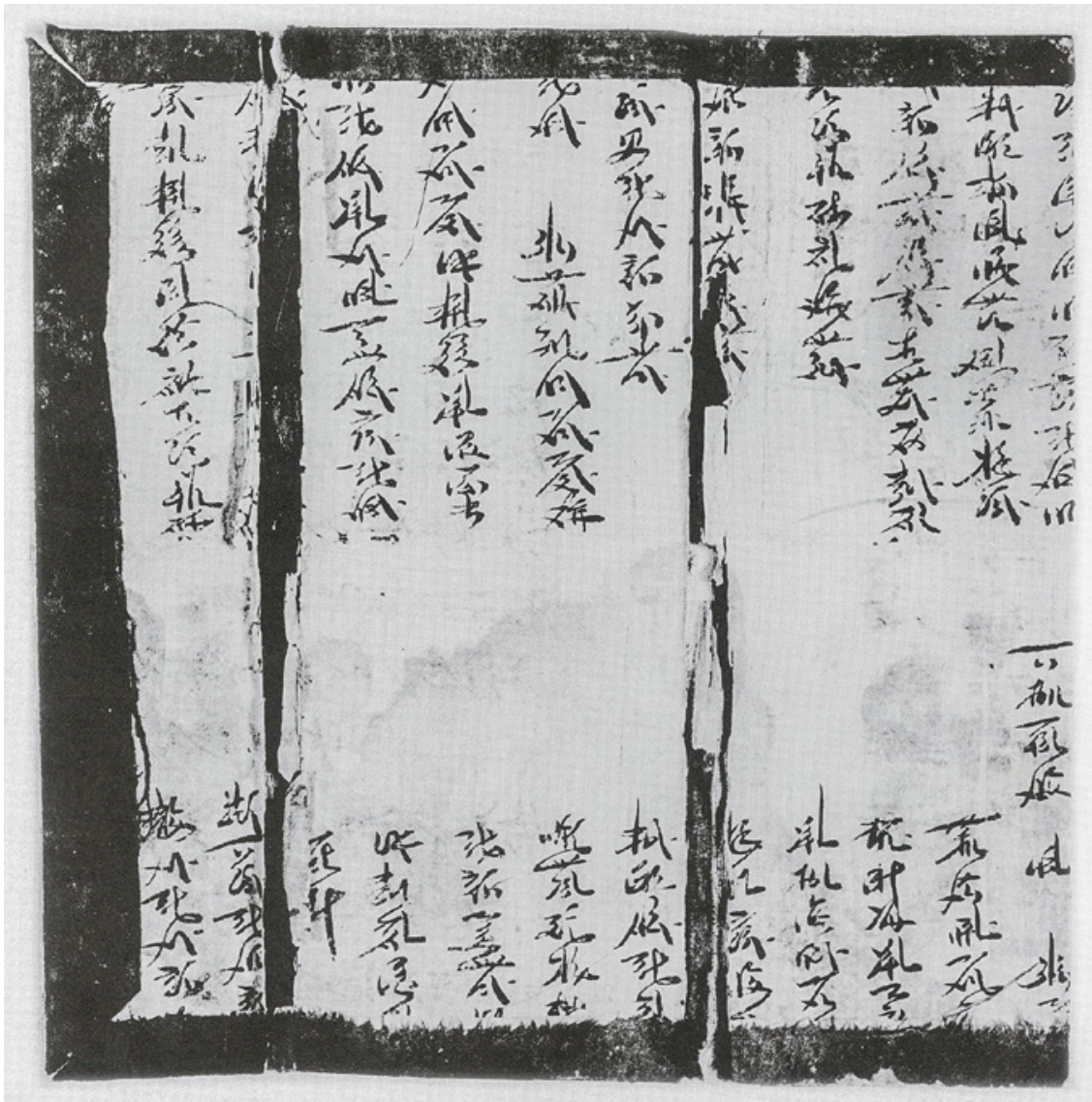

FIGURE 54 Инв. No. 441: Grain account

capital). They point to the possibility that these are records of the army's transportation of grains from the military supervisory district of Khara-Khoto to the imperial capital Zhongxing (present-day Yinchuan of Ningxia) by the unit of liliu. The amounts of grains recorded in these accounts are in large numbers, such as "189 dan and 3 dou" in Russian manuscript Инв. No. 438 (top page, line 3) and "296 dan, 2 dou and 5 sheng" in Инв. No. 723 (bottom page, lines 10-11). These numbers probably indicate the amounts of grains that the single liliu was put in charge of transporting to the capital.

The statistics in the grain accounts are compiled by months and years.

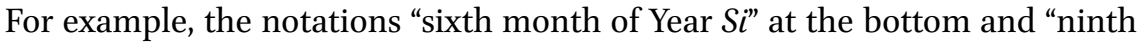
month" at the top of Russian manuscript Инв. No. 438 indicate that this is a grain account from the year Si. Similar notations of time include the lines "Year $S i$ [ ] month" at the bottom and "[year], tenth month" at the top of Инв. No. 441, as well as "Year $S i$, eleventh month" and "Year $S i$, last month" in manuscript 


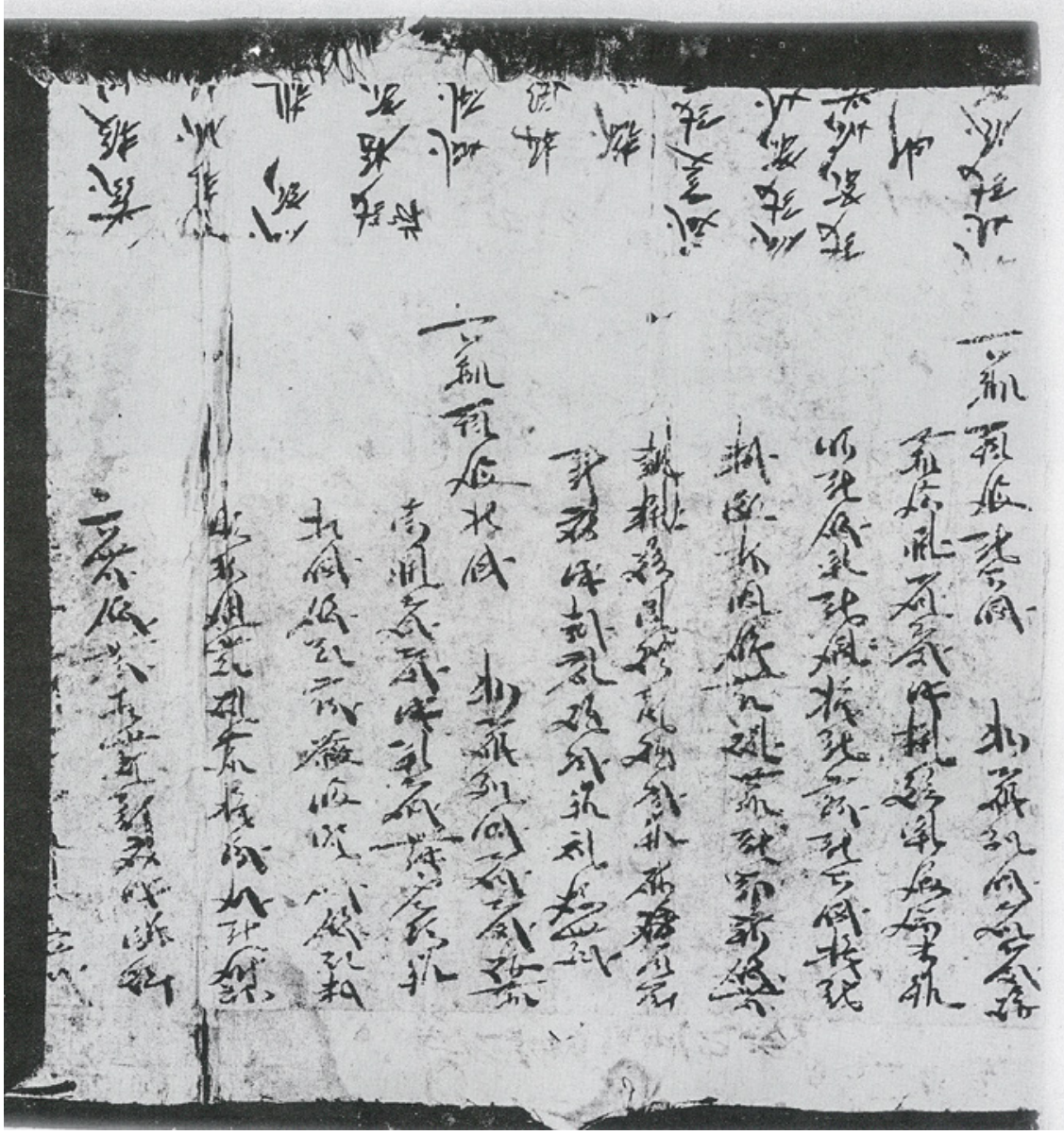

FIGURE 55 Инв. No. 723: Grain account

Инв. No. 723. There seems to be no doubt, then, that all these documents ought to be dated to the year of Si. The entries in these documents are sorted by months, which means that those beginning with 'June' are accounts for the June-July period, and entries that begin with 'September' are grain statistics for the September-October period. Likewise, entries beginning with the last month of year Si extend to January of the following year of $W u$.

Despite general illegibility of the documents due to heavy damages and missing characters in almost every line, there remains valuable information in the more recognizable entries. For example, the records of " 45 men in an entire month from Oct. 2oth to Nov. 2oth" and "13 dan \& 5 dou" found at the bottom of manuscript Инв. No. 723 (lines $3-5$ ) yield the result 3 dou of grains 
per person during this month. In another record, " 45 men in the entire month from August 1oth to September 1oth" and "thirteen dan [?] dou of millet" in the upper section of manuscript Инв. No. 438 (lines 5-8) suffers from the loss of a missing word, likely the character for "five," based on information from adjacent documents. In this way, the daily provision per person also turns out to be 3 dou per person for the month (i.e., 1 sheng per day). This may be the grain subsidy provided to soldiers in a given liliu.

The Laws of Heavenly Prosperity offers detailed rules and regulations for the transportation of materials from local areas to the imperial capital:

The many kinds of government-owned livestock, grains, cash and other properties that do not fall under the jurisdictions of Strategic Regulatory Commissioners (Jinglueshi), and which the staff of the bureaus in charge of storage have not, ${ }^{2}$ based on their location, distributed to the relevant offices of local towns, districts, commandaries and military commissions for review, should be studied and dispatched all at once within fifteen days of their transfer. It is also necessary to clearly indicate the number of days required for their transportation based on their distance from the Imperial Capital and the time it requires for the bureaus in the Imperial Capital to review them.

The two military supervisory commissions are obliged to transport goods to the jurisdiction of the imperial capital within forty days since the time of the dispatch; the political offices in the imperial capital are required to finish the review process in sixty days; the Bureau of Review conduct inspection for fifty days: Shazhou, Guazhou.

The two military supervisory commissions are both obliged to transport goods to the imperial capital within thirty days since the time of the dispatch. The political offices of the Imperial capital are required to finish the review process within sixty days; the Bureau of Review conduct inspection for sixty days: Suzhou, Heishui (Khara-Khoto) ... ${ }^{3}$

2 TN: This is a literal translation. According to Tangut laws, it is standard procedure for the local offices to review the goods and statistics, one level at a time, before referral to the office and the inspection bureau of the imperial office. Here, the text may refer to cash, goods and resources directly supplied to the capital. In general, finances of the military districts, the capital, and the empire as a whole are separated, not without overlaps.

3 Revised Laws of Heavenly Prosperity 17, "Rules concerning the departure of goods from the storage," p. 544. 


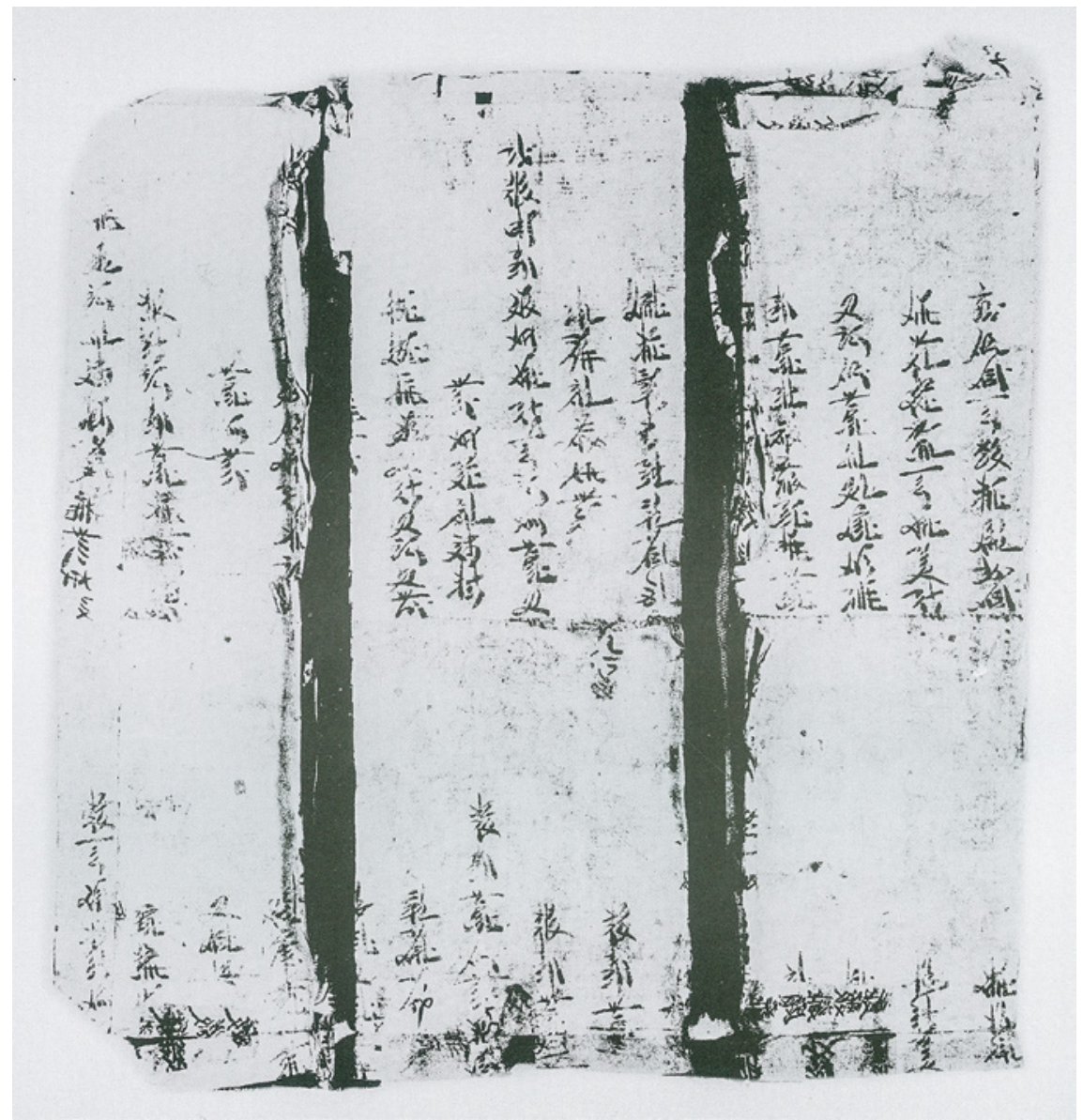

FIGURE 56 Инв. No. 2998: Grain account

This legislation concerns the time constraint on the transportation of goods from various local districts to the imperial capital. Sending goods and supplies from Shazhou and Guazhou, prefectures further from the destination, usually took about 40 days. For cities Suzhou and Khara-Khoto, time of transport was 30 days. This law coincides with and confirms the ' 30 days' recorded in the Khara-Khoto grain accounts.

Some grain accounts show unusually large numbers in the hundreds and even thousands of dan. For example, Russian manuscript Инв. No. 2998 records a total of 3611 dan. Manuscript Инв. No. 2998 is a grain account piece on a $33.3 \times 32.3$ hemp paper used as the layer of a book cover. The document 
is patched together with multiple broken pieces and divided into upper and lower parts, featuring 14 and 15 lines of Tangut cursive writings, respectively. ${ }^{4}$

According to lines 8-12 of the document, "Of the coarse and refined kinds of grains in the amount of $3611 \mathrm{dan}, 4 \mathrm{dou}, 8$ sheng, $6 \mathrm{ge}$, there are: grains 2088 dan, 8 dou, 3 sheng and 6 ge; wheat 1512 dan 3 dou 4 sheng; millet 5 dan, 3 dou, 2.5 sheng." The first batch of (coarse) grain is in the large number of more than two thousand dan. The second type of grain, though officially unknown due to missing characters at the corner of the manuscript page, is judged to be 'wheat,' given that the third category is listed as 'millet.' The reason is simple: both 'grains' and 'millets' are considered to be 'coarse' ('assorted' or 'miscellaneous' grain types), so, without the refined 'wheat' listed in between, this document could not have claimed to cover both the 'coarse' and the 'refined.' The missing numeral ' 3 ' dou in 'wheat' can also be inferred by a simple subtraction of the numbers in the first and third categories from the total sum.

\subsection{Grain Accounts by liliu}

Grain accounts are sometimes registered by liliu, the basic unit of organization in Tangut communities, roughly equivalent to li (as in lijia) in the Central Plains. Grain accounts of similar types include manuscripts Инв. No. 4762-4 (liliu grain account, $20 \times 40 \mathrm{~cm}$ hemp paper, 15 lines of Tangut cursive with signatures, edits and erasures) and Инв. No. 4762-5 (liliu grain account, hand-written manuscript, $19.3 \times 89.2 \mathrm{~cm}$ hemp paper, 37 lines of Tangut cursive with signatures, edits and erasures). ${ }^{5}$

The first two well-preserved documents are similar in format and cal-

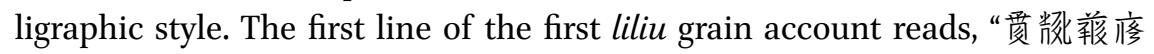
很䊏[?]": the first and second characters may be literally translated as "soft grains," a general reference to grains and food. A similar word to the first char-

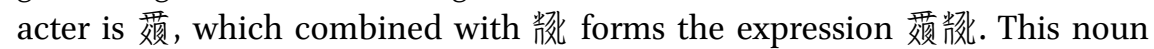
is translated to the Chinese 斛㪷 (food and grain) in the Fan-Han Pearl in the Palm. The last character in the place of the question mark is illegible, but it should not prevent us from translating the whole phrase into the like of "transfer four kinds of grains (liu)." This is followed by the grain account of one unit of liliu. The second document contains the accounts of two liliu units. Overall, given the registration of four liliu accounts, there seems to be one more left undiscovered.

4 Russian Collection of Khara-Khoto Manuscripts 13, p. 163.

5 Russian Collection of Khara-Khoto Manuscripts 13, pp. 278, 279. 
But in the surviving records of three liliu accounts, the first line begins with

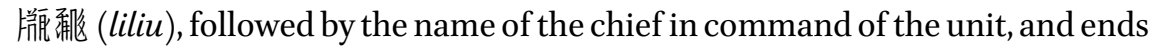
with the two characters 登路 (the local administrative bureau), signifying that the staff listed below are under the authority of the liliu chief. Thereafter, each line records the names, under which appear the statistics of grains. In general, each line contains information on the amounts of grains under two names.

For example, manuscript Инв. No. 4762-4 records the grain statistics under 23 names, which are, in order: 300, 200, 50, 50, 60, 30, 20, 30, 10, 20, 10, 20, 10, $5,15,5,5,5,5,10,3,3,5$ dan. The document records the amounts-as much as 300 and as little as 30 dan - but not the types of grains. The grain accounts of 2 liliu units, recorded in manuscript Инв. No. 4762-5, contain statistics under 33 and 31 men, respectively, each with cursive signatures and finger stamps at the end. Manuscript Инв. No. 4762-4 ends with the three characters 橦㤏狣 (twenty-nine); the account of the first liliu in Инв. No. 4762-5 also ends with the signature of "twenty-nine," whereas the record of the second liliu shows 多 纹 (day one) instead. This is enough evidence to indicate that these are dates, signatures and finger stamps at the end of an official account, and that the first two documents were signed on the 29th - the last day of a 'short month' in the lunar calendar - whereas the latter was signed on the day after, on the first day of the following month.

An analysis of these grain accounts suggests that they do not concern household land taxes. The amounts of grains are in large numbers, from dozens to hundreds of dan, which greatly exceed the magnitude of even the severest rate of taxation. Moreover, we know that the grain versus wheat ratio in land taxes is about 4:1, which finds no echoes in these accounts. Nor do they resemble poll

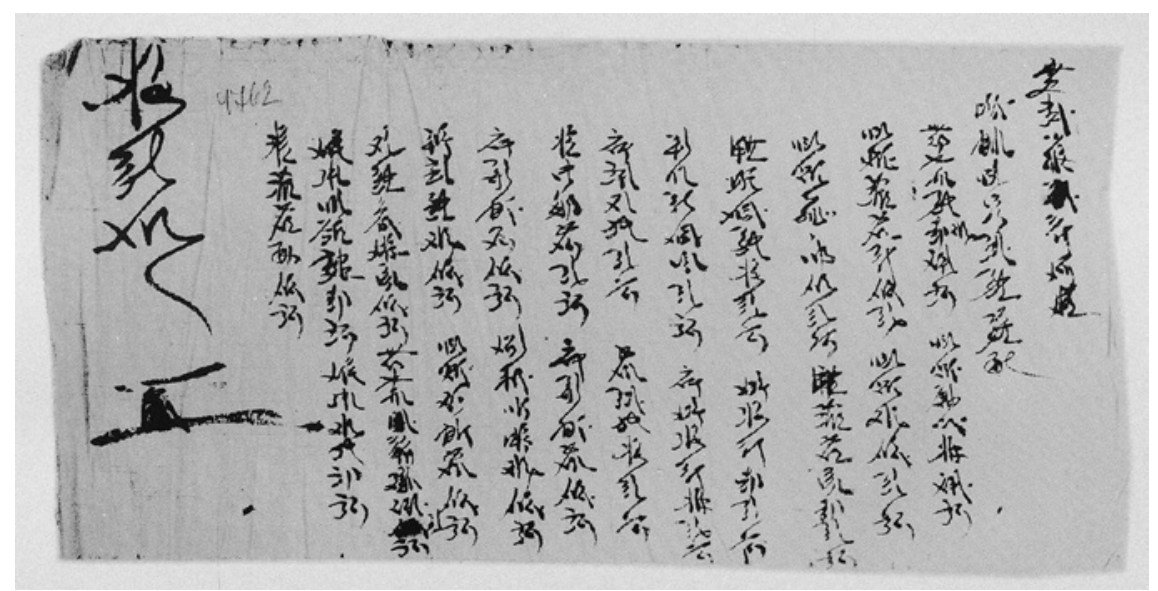

FIGURE 57 Инв. No. 4762-4: Liliu Grain account 


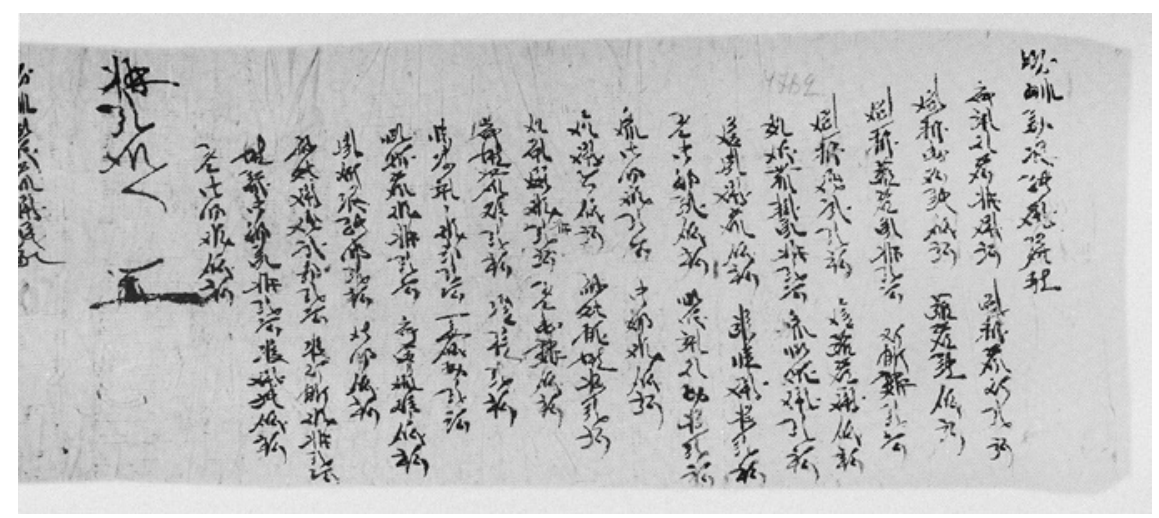

FIGURE 58 Инв. No. 4762-5 (1): Liliu Grain account

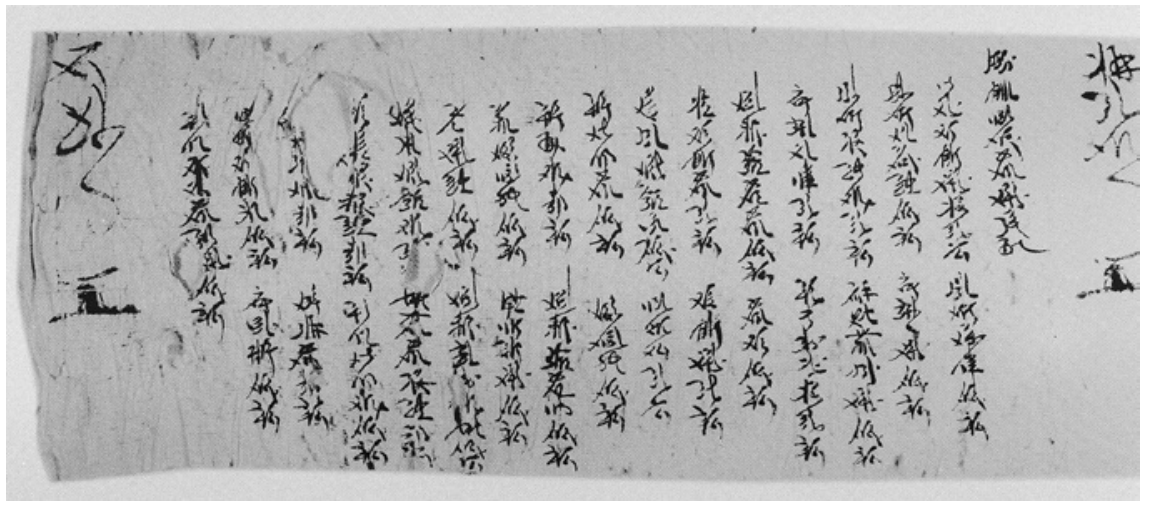

FIGURE 59 Инв. No. 4762-5 (2): Liliu Grain account

taxes, which are approximately 3 dou per adult and 1.5 dou per child. Given the large sums, and the fact that for records on so many households, the smallest unit of weight measurement in the first two documents is dan, rather than dou or sheng, they cannot be poll taxes, either. A quick comparison with the water and irrigation tax records also rules out this possible conjecture. So, what is the nature and purpose of these grain accounts?

Because of the large grain-per-household numbers, usually in the unit of dan, it is possible that they are accounts of grains distributed and transported to each household. Russian manuscript Инв. No. 4762-4 mentions the identity of shijun at the beginning, after which is recorded the amount of grains in 300 dan. We have mentioned that the shijun are semi-slaves, without personal freedom, at the bottom of Tangut society. They are least likely to be levied such large amounts of grains by the government, but they are the ones who 


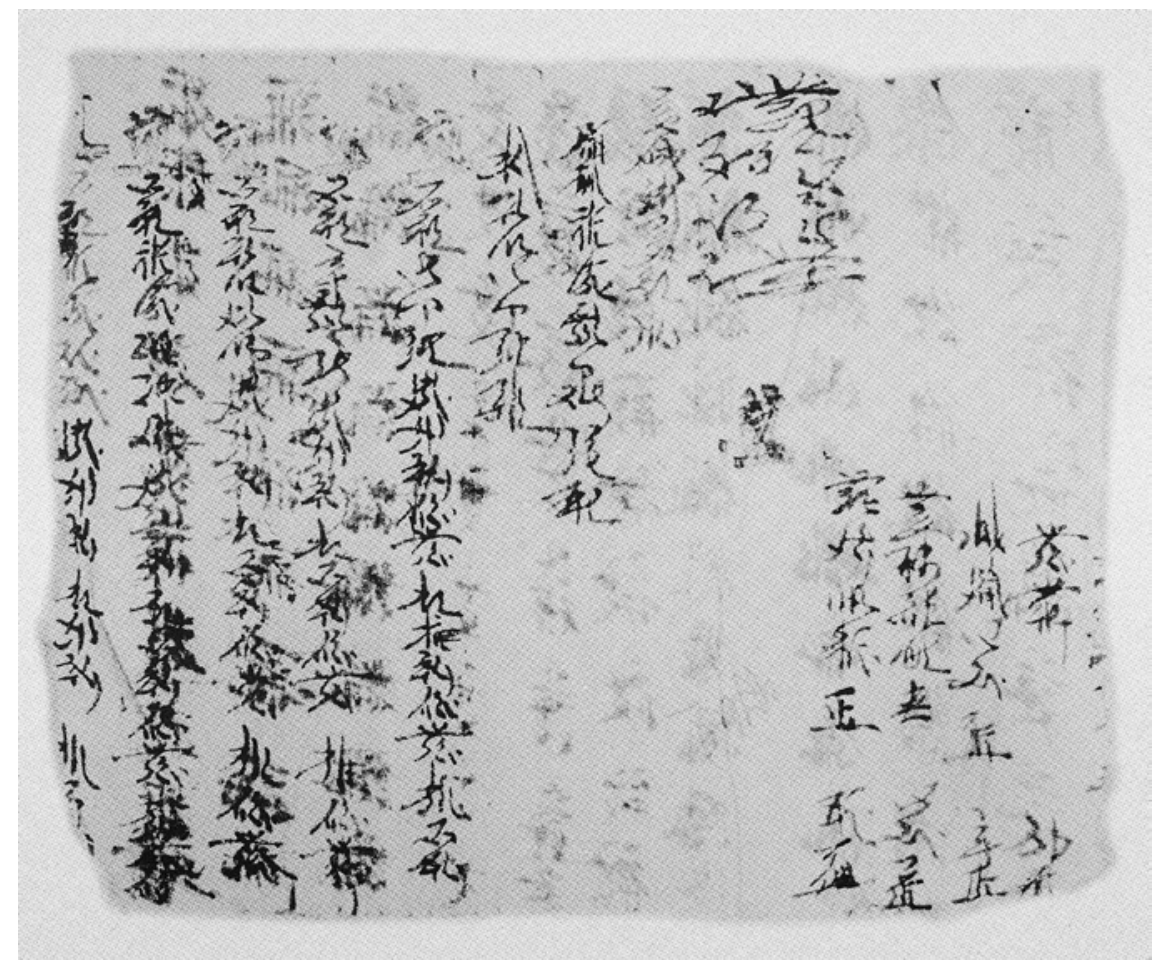

FIGURE 60 Инв. No. 4762-8: Grain account

provide labour service to transport the largest amounts of grains from one site to another. The grains are transported from the liliu to the individual households, which is an accurate portrayal of the socio-economic reality at the time. In particular, manuscript Инв. No. 4762-4 lists the "the transferor of grains" in the first line, the title of which further implies and corroborates the purpose of these grain accounts. It is likely that they are accounts of various sums of grains transferred and transported by staff in the organization of liliu.

The following Russian manuscript Инв. No. $4762-8$ is another grain account on $18.7 \times 23.5 \mathrm{~cm}$ hemp paper featuring 13 lines of Tangut cursive and signatures. ${ }^{6}$

This piece of document lost some of the first and last portions of its content, but given the signature and finger stamp, it is possible to categorise it as an account of grain statistics. Given that it also features the first half of a second liliu account, the manuscript seems to contain at least the accounts of two

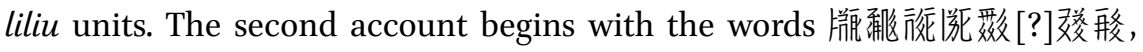

6 Russian Collection of Khara-Khoto Manuscripts 13, p. 281. 


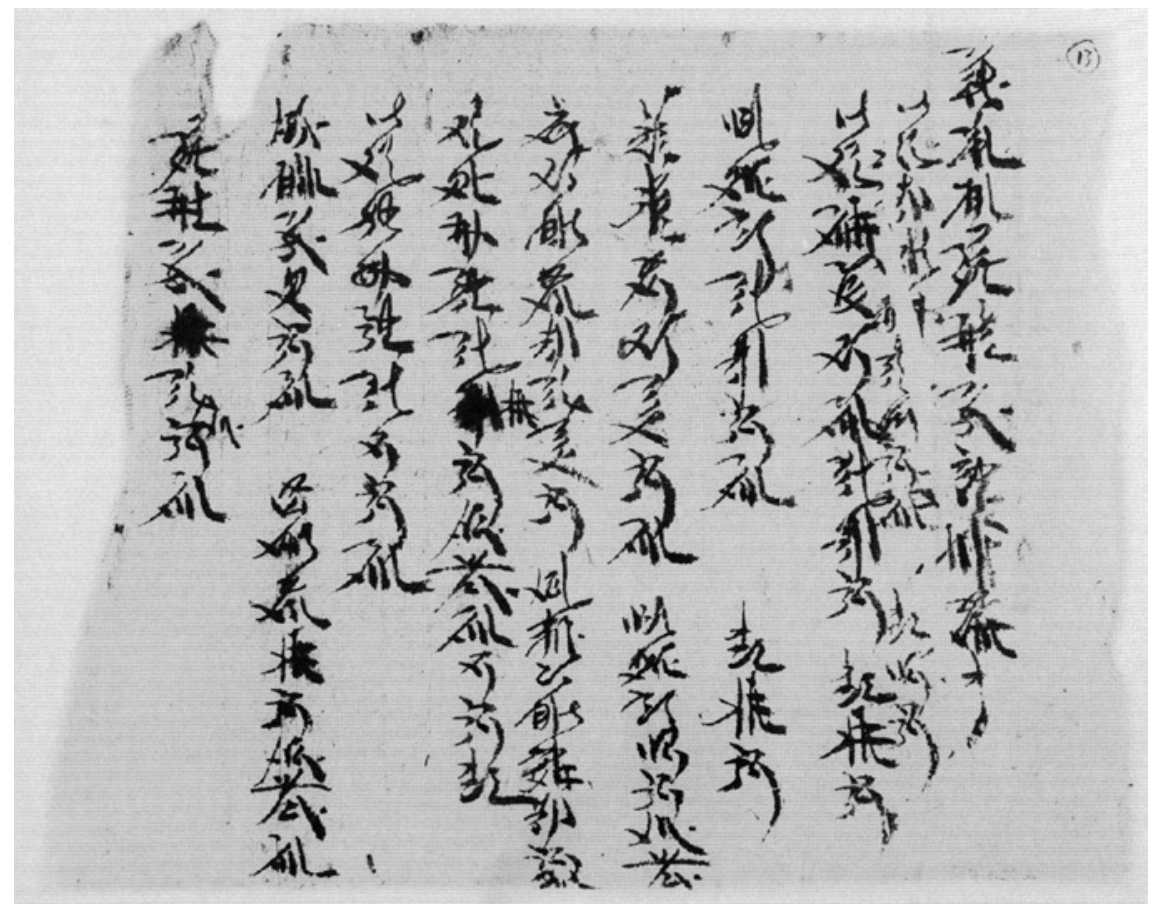

FIGURE 61 Инв. No. 6377-12: Liliu Grain account

meaning "liliu Luopujiu [?] bureau staff." As already mentioned, the characters for "Luopujiu[?]" are the name of the leader of the liliu concerned, whereas the "bureau" refers to the staff under his administrative authority.

The document shares some similarities with the grain accounts mentioned above, but remains different in several aspects of its format:

1. The unit of jia is found under liliu, with the surname of the jia chief recorded as Yehe;

2. Indication of two characters 多䊂 (one household) before the lines;

3. Grains are recorded separately under each type: barley, wheat, millet, etc.;

4. The smallest unit is no longer dan, as in the three aforementioned accounts, but in both dan and dou.

There are a few additional accounts of a similar kind. One example is manuscript Инв. No. 6377-12, a handwritten liliu grain account on a $19.5 \times 24.8 \mathrm{~cm}$ hemp fragment paper, with ten lines of Tangut cursive as well as signs of erasures and edits. ${ }^{7}$

7 Russian Collection of Khara-Khoto Manuscripts 14, p. 143. 


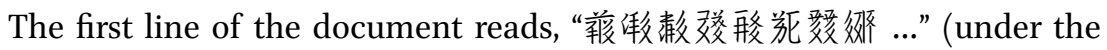
managerial authority of the transferors and the bureau staff ...), followed by the kinds and amounts of food by persons: "Meiqi Nazhengji, assorted grains 13 dan, wheat 2 dan." The difference lies in the details of the last two lines: " 8 dan of assorted grains in the liliu," "Jianli[?] 2 dan 5 dou of assorted grains," "bureau staff, 19 dan of assorted grains," etc. These three accounts concern the basic organisational unit of liliu. To ascertain whether the grains hereby concerned are supply reserves requires further archival and archaeological research.

\subsection{Deficit Supply Accounts}

Among the numerous and diverse Tangut social documents, manuscript Инв. No. 6569-1 stands out as a curious fragment page. Handwritten on an $18.7 \times 37.5 \mathrm{~cm}$ hemp paper, the 18 lines of Tangut cursive writings (with edits and emendations) record many dates, under which are found grain statistics in relatively small numbers. In light of certain decrees in the Laws of Heavenly Prosperity, it appears to be a 'deficit supply account.'

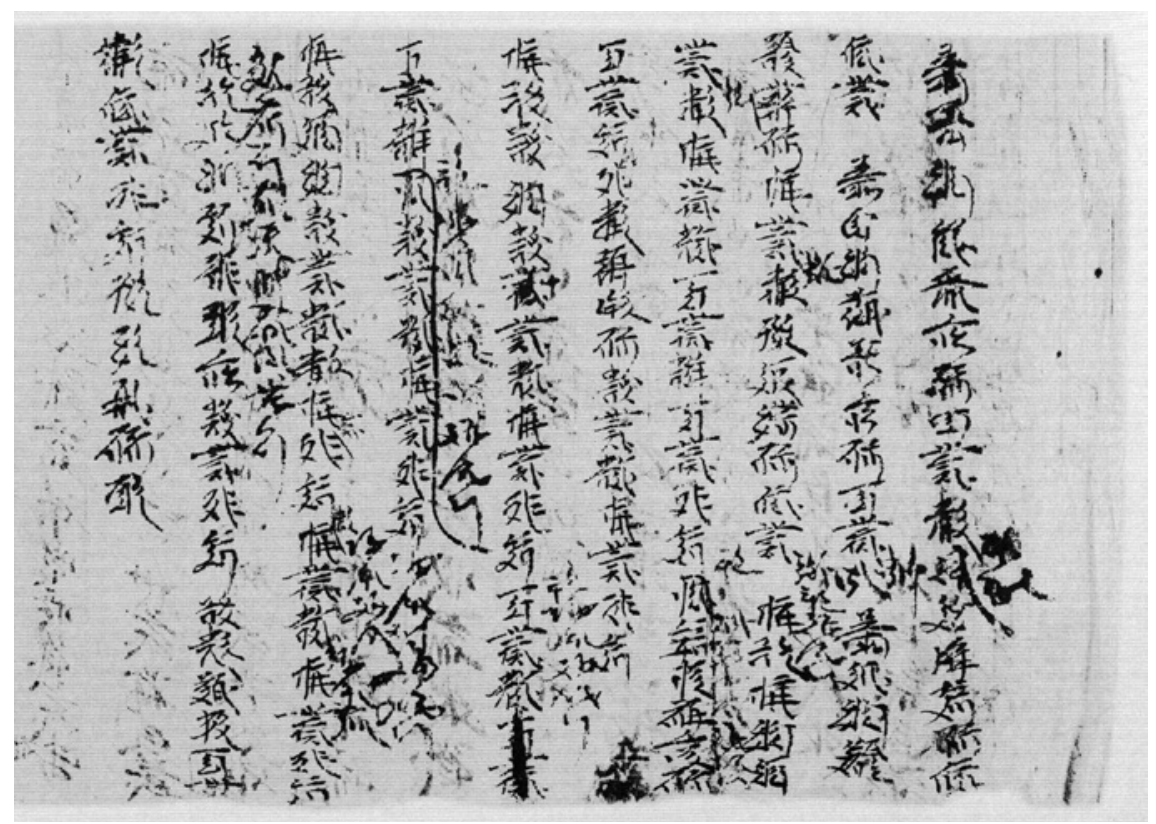

FIGURE 62 Инв. No. 6569-1: Deficit supply account

8 Russian Collection of Khara-Khoto Manuscripts 14, p. 157. 
Translation:

On the seventeenth day, to supply the [official] in charge of burdentransport, 1 sheng; and to [?] 父条拼㸚 [da kia gju_] Five[?]

5 sheng. On the eighteenth day, to the one in charge of the task 1 dou of millet; on the nineteenth day, to supply the one

responsible for the birds 2 sheng of flour, and to supply the high official 5 sheng of flour; On the twenty-second day;

sheng and 2 dou of flour; 1 dou of rice, 1 dou of grinded grains; and to sup-

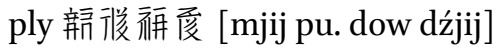

1 dou of grinded grains, and to supply the envoy 3 sheng of flour; 2 dou of grinded grains.

On the twenty-third, to supply 3 sheng of flour, 2 sheng of grinded grains, 1 dou of flour

1 dou of rice, and 3 sheng of flour, 2 sheng of grinded grains

On the twenty-fourth, 3 sheng of flour and 2 sheng of grinded grains, 2 dou of flour, 2 dou of grinded grains

On the twenty-sixth, to supply [?] 到椱废? 3 sheng of grinded grains. Ten scrolls [bureau] Price 1 (dou or sheng) and 5 dou of grinded grains, to supply 5 jin.

From the incomplete translation above, it is easy to see that these are provisions supplied to government staff. Some of them are referred to by titles, as in "the one in charge of transporting the burden [?]," the one "holding the birds," and a higher-ranking official in the capital. Others are personal names, such as

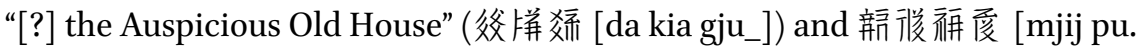
dow dźjij]. From day 17 to day 26, there are accounts for 7 days. Some of them do, whilst others don't specify the recipient. If no recipient is named, then it is presumed that it is the same recipient as in the previous document. Overall, this records the daily provision of grains that a given department supplies to its employees. The Laws of Heavenly Prosperity stipulates the rules concerning the salaries of regulators in both larger and smaller 'Bureaus of Review,' in charge of checking the statistics of military-owned livestock.

The following are the amounts of provisions provided to the staff in the Bureaus of Review and Inspection, according to their ranks:

A Senior Official enjoys a slaughter every 10 days, 4 sheng of rice or grains per day; of the 2 horses, each one is allocated 7 sheng, the other 5 sheng; a Junior is allotted 1 sheng of rice. 
$\square$ An official, such as a Secretary in the Bureau of Review and Inspection, enjoys a slaughter every 15 days, 1 sheng of rice per day; 5 sheng for the horse; a Junior is allotted 1 sheng of rice per day.

Government employees: Antou (Clerk at the Desk) and Sili (Staff in the Office) both enjoy one slaughter every 20 days; each of them is allotted 1 sheng of rice per day; a Junior and a Keeper of the Rod each has 1 sheng of rice.

Provisions granted to the employees in the higher and lower bureaus of Livestock Review and Inspection, according to ranks:

A senior official enjoys a slaughter every 7 days, 4 sheng of rice or grains per day, of which there is 1 sheng of rice; food for 4 horses, 7 sheng for one horse, 5 sheng in case of the 3 horses; for the three children, there is 1 sheng of rice per day.

$\square$ All serving agents in the Bureau of Review and Inspection and others enjoy a slaughter every 15 days, 1 sheng of rice per day, 5 sheng of food supply to the horse, as well as 1 sheng of rice to a single child.

The two lower-level Antou and Sili officials enjoy a slaughter every 15 days; to each of them, there is a supply of horse food in 5 sheng; to each of them there is 1 sheng of rice per day; to the one child, there is 1 sheng of rice.

Each of the two men receive an allocation of 1 sheng of rice per day:

One in charge of the sticks.

One in charge of equipment. ${ }^{9}$

A comparison of the document above to the stipulations of provisions in the Laws of Heavenly Prosperity suggests that the document records salaryprovisions to government officials on active duty. There exist, however, some differences between the two. Whereas in the Laws of Heavenly Prosperity, government staff receive not only grains, but also meat as well as food for their horses, the two documents here mention only grains, not meat. This is perhaps the case for lower-ranked staff members.

9 Revised Laws of Heavenly Prosperity 20, "On the Different Degrees of Crimes and Liabilities," pp. 613-614. 


\section{$2 \quad$ Accounts of Properties}

There is a large quantity and wide array of property accounts in the corpus of Tangut social documents. They furnish us with abundant information on goods and materials, cash and properties, as well as livestock and miscellaneous possessions. However, many of them remain uninterpreted, due to the illegibility of some cursive writings coupled with damages and fragmentation.

\subsection{Accounts of Cash and Valuables}

Manuscript fragment Инв. No. 4761-11, an account of cash and properties with prints and signatures in large characters, is a formal record registered by the government. This is a handwritten manuscript roll on an $18 \mathrm{~cm} \times 42.4 \mathrm{~cm}$ hemp paper with 28 lines of Tangut characters in the cursive style. It features signs of edits and erasures, and prints and signatures, despite some damages in the beginning and lower sections on the right. ${ }^{10}$

Despite the damages to this manuscript, the names are still preserved. In this context, the document appears to be a property account for a transac-

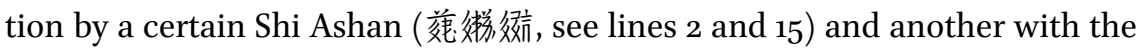

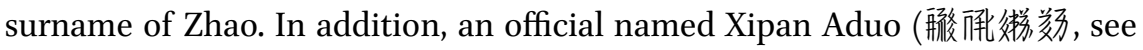
lines 11, 16, and 25) takes part as a witness on behalf of the government.

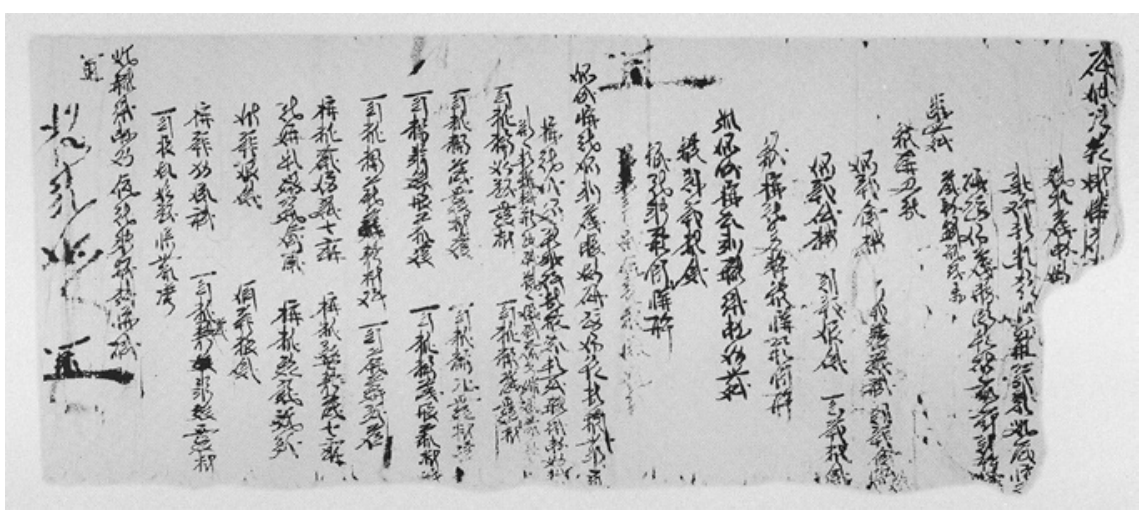

FIGURE 63 Инв. No. 4761-11: Account of cash and properties 
There are several names of properties in this document. From lines 6-8, there are:

Properties of eight kinds:

$4 p i$ of silk: $1 p i$ of rouge-dyed silk, $3 p i$ of silk [??]

4 pi of cloth: 3 pi of Fan cloth, 1 pi of Han cloth

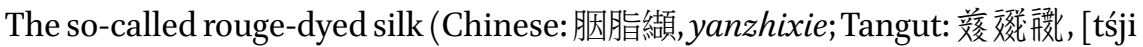
$\cdot \mathrm{ja} \sim \mathrm{xjij]})$ is a phonetic transliteration from Chinese. The first two characters are used specifically to represent the Chinese sounds for "rouge" and "blush" cosmetics in the Pearl in the Palm. The third character [xjij], which corresponds to a range of modern sounds from xie, xing to xian, sometimes appears as a last name. But here, it refers to a kind of refined silk with floral decorative patterns (Chinese: 䋶). This type of silk is also mentioned in Khara-Khoto manuscripts of Chinese trade records. ${ }^{11}$

More property names are mentioned in line 11:

\section{Properties: 3 pi of Han cloth}

17 items are mentioned in the 9 lines from 18-26: two in each of 8 lines, and one in the last line. Most of them are textile products, such as " 6 pi of Fan cloth" and "4 pi of Han cloth," but many others have not yet been accurately interpreted.

Various amounts of cash are also mentioned: 27 guan (line 10), 10 guan (line 12), and the 50 guan of Xipan Aduo (line 25).

Specific dates are indicated in the manuscript: 2nd April (line 11, Xipan Aduo[?]), 24th April (line 15), etc. The large characters "twenty-four" signed at the end of the document may also refer to the date.

Overall, this is a social document with a large number of preserved characters, and therefore a great deal of information. It is also worth noting that the manuscript mentions both "Fan cloths" and "Han cloths." The first character of the "Fan cloth" (Tangut: 级倣) refers to the Dangxiang Tangut identity, the ruling ethnic group in Western Xia. The expression is clear in distinguishing Tangut textiles from Han Chinese products (Tangut: 䊅㒄). The fact that Fan and Han cloths were traded in markets and used by local households at the same time also points to the possible existence of a Tangut textile industry before the Dangxiang integrated into the Han Chinese economy after the great

11 Du, Jianlu; Shi, Jinbo. Xixia Shehui Wenshu Yanjiu [西夏社會文書研究]: A Study of Tangut Social Documents. Shanghai: Shanghai Ancient Works Publishing House, 2012, pp. 257, 258. 
northern migration. It seems that after entering into north-western China, the Tanguts did not replace their own cloths with Chinese merchandise, but continued to produce cloths with ethnic characteristics, and used them along with the finer Chinese products. If this is true, then the prevalent thesis that no Dangxiang Tangut textile industry existed surely requires modification. As to whether and how much of the Fan and Han cloths are made of hemp or cotton, we do not yet have sufficient sources to make the right conclusions. But this manuscript, rich in content and full of information, is to be further studied and interpreted as new data emerge.

\subsection{Accounts of Livestock}

It has been mentioned that many households' self-reports (shoushi) contain information on not only population but also the ownership of livestock. But many manuscript fragments only feature the types and statistics of livestock. Whether or not these records belong to the category of 'household register' requires further investigation. For example, manuscript No. $4761-15$ is a livestock account handwritten on an $18.5 \times 37 \mathrm{~cm}$ hemp paper, which contains 14 lines of Tangut cursive writings. ${ }^{12}$

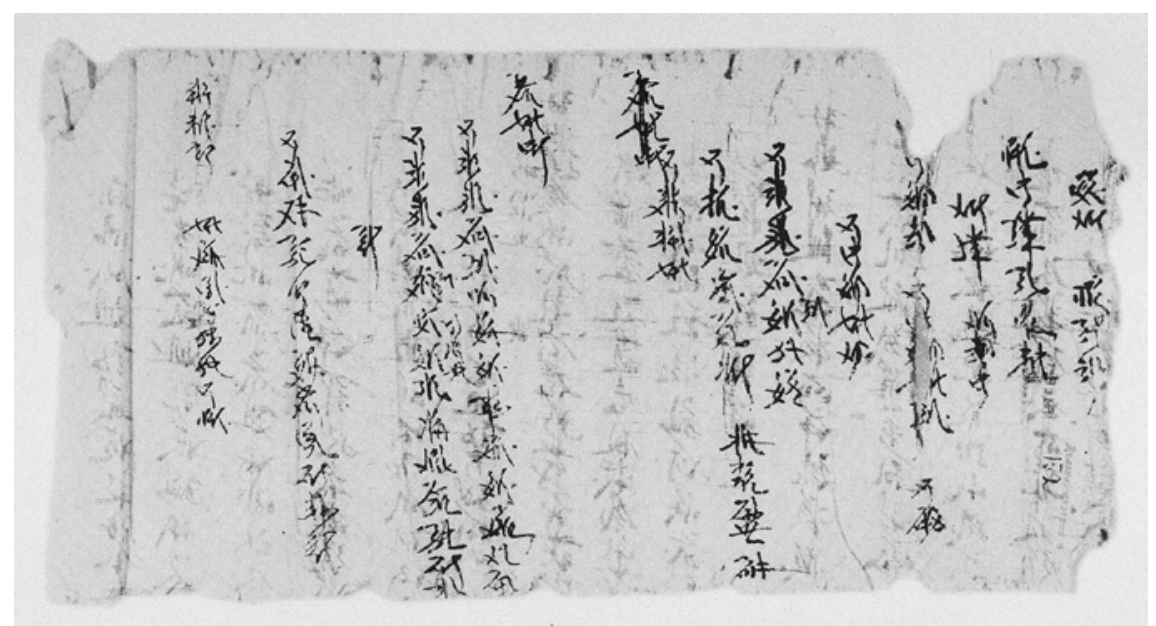

FIGURE 64 Инв. No. 4761-15V: Livestock account

12 Russian Collection of Khara-Khoto Manuscripts 13, p. 273. 
This document is a rather detailed account of livestock statistics. It regrettably suffers some damages at the beginning, and many words remain blurry and ineligible. But the following is a tentative translation:

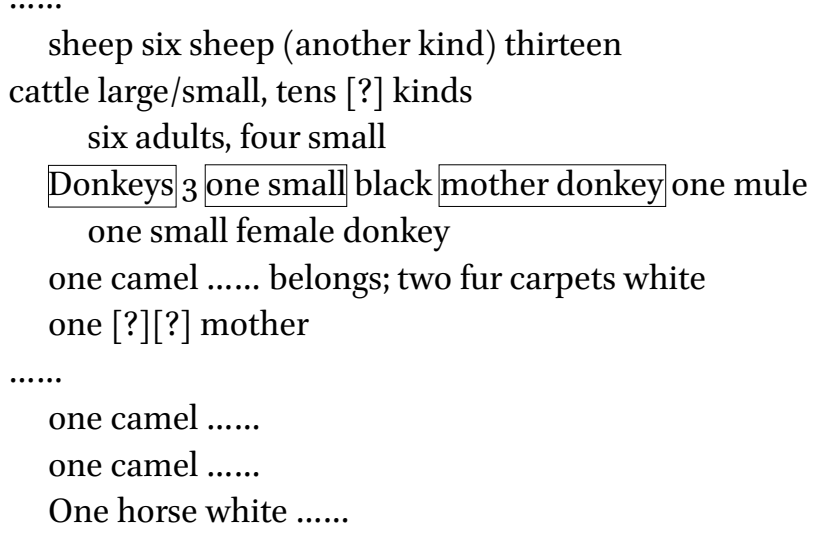

This is possibly a detailed statistical record of the livestock owned by a single household, including the types, numbers, sizes, fur-colours and even ages of the animals. The exhaustive and extensive nature of the record demonstrates the great attention paid by the government to the herding and pasturing industry. According to the Laws of Heavenly Prosperity, livestock is divided into private and public ownerships. The government owns animals on public pasturelands, whereas individual households keep their own livestock on private lands. ${ }^{13}$ The small numbers indicated in this particular manuscript seem to suggest that they are private possessions.

Sometimes, livestock statistics of more than one household are compiled together. One example is manuscript Инв. No. 345, a handwritten account of livestock and properties on a $32.3 \mathrm{~cm} \times 13.2 \mathrm{~cm}$ hemp paper (two fragments stitched and pasted together), which served as the layering paper to a book cover. The two pages feature 7 and 5 lines of Tangut, respectively. ${ }^{14}$

\footnotetext{
13 Revised Laws of Heavenly Prosperity 13, p. 467.

14 Russian Collection of Khara-Khoto Manuscripts 12, p. 103.
} 


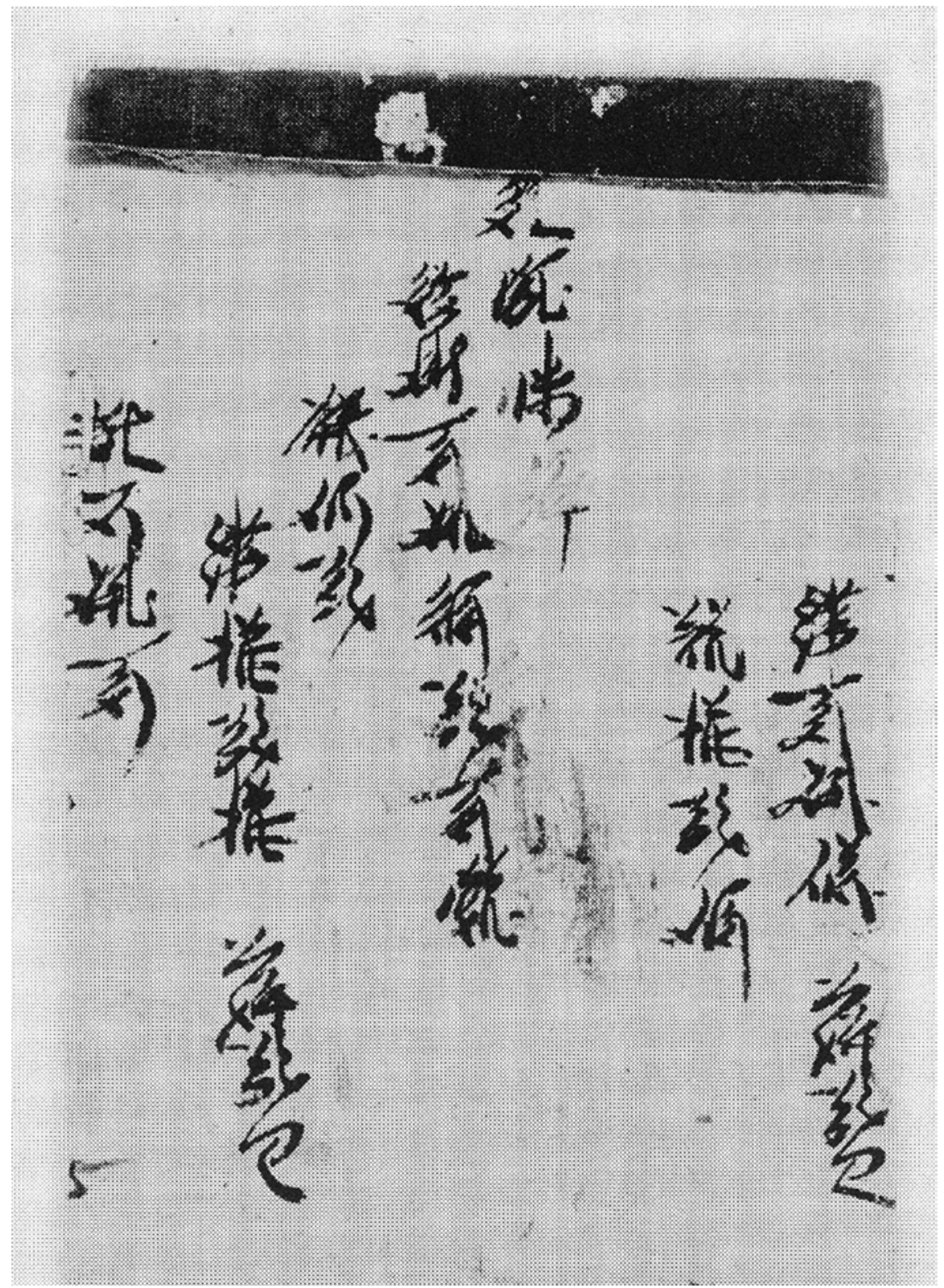

FIGURE 65 Инв. No. 345: Livestock account 
The following is a literal translation:

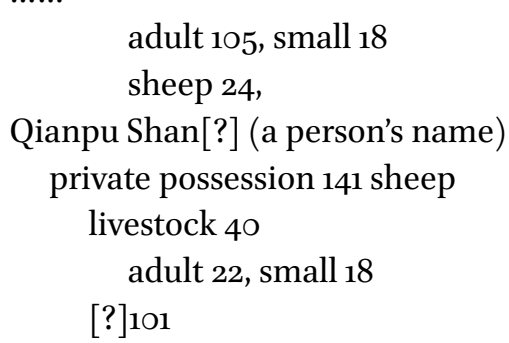

Obviously, this fragment contains the livestock statistics of at least two households. It is possible to speculate thence that the Tanguts kept a special form of document on livestock statistics by individual households.

\subsection{Accounts of Miscellaneous Properties}

Some of the manuscripts unearthed at the site of Khara-Khoto contain information on a wide array of miscellaneous objects. For example, manuscript Инв. No. 7892-9 is a property account in the year of You. It is a hand-written manuscript on two pages of hemp paper $(20 \mathrm{~cm} \times 10.8 \mathrm{~cm}$ and $20 \mathrm{~cm} \times 14 \mathrm{~cm}$, respectively). There are 6 lines of Tangut writing in each document, and the second page features a signature and finger stamp. In line 2 on the left page-fragment, there is a date of "year of You, first (month), day twenty-five." In the original text, "five" comes after "day," but the hand-writer uses the $\sqrt{ }$ sign to correct the typo. Furthermore, it is unclear which year of You it is. ${ }^{15}$

There remain 6 lines on the right page-fragment, among which are listed the following properties:

Thin clothes 6 stacks, 2 axes, 1[?]

[?] [?] vinegar 3, 3 Spider (skimmer), ${ }^{16}$ millet [?] pearl

2 axes[?] 50[?] 1 iron[?]

\footnotetext{
15 Russian Collection of Khara-Khoto Manuscripts 14, p. 207.

16 Tangut: 弱謊 [tśiow lji], may be tentatively translated as the Chinese 笑篱 (the utensil, Spider). In the Pearl in the Palm, however, the Tangut phrase for 笑篱 is different.
} 


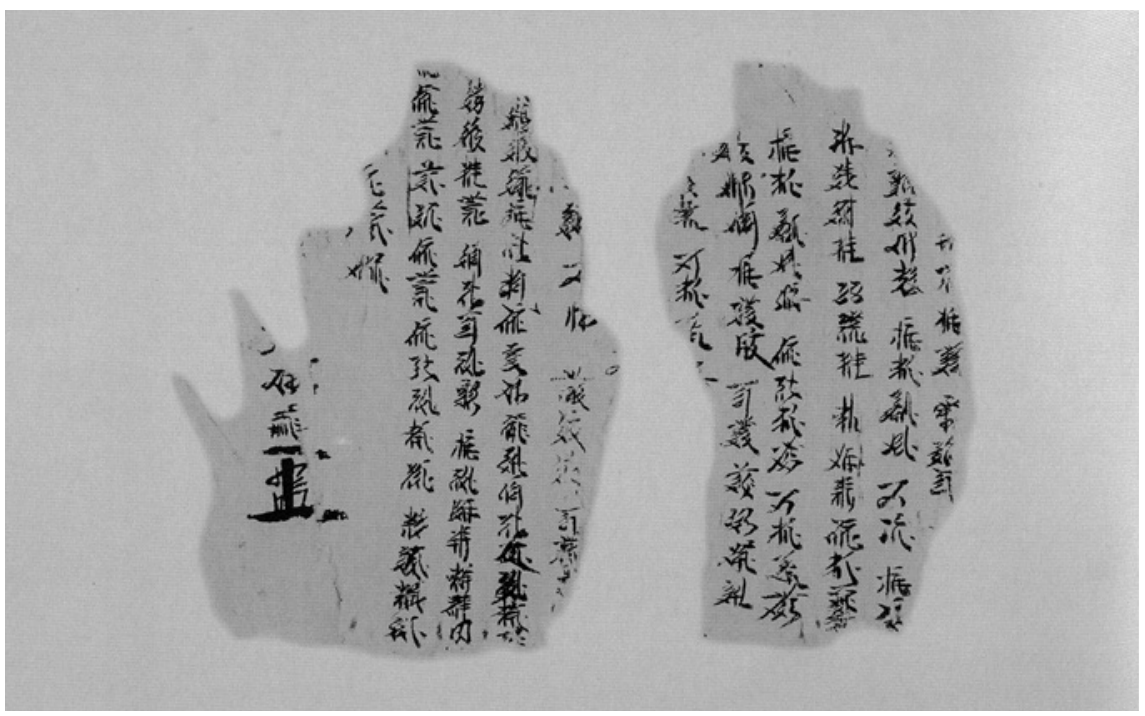

FIGURE 66 Инв. No. 7892-9: Property account in the year of You

On the left page-fragment, there are a number of properties listed under the name of a certain $\mathrm{Li}$, which may be roughly translated as below:

...... Year of You, first month, day 25, Li [?] [?] [?] 45 jin of glutinous rice ..... [?] [?] 3 sheng, 41 jin of butter, 2 jin of dou $z u o^{17}$ white rice 8 ...... ...... 5 sheng, geng [?] 5 sheng; 5 ojin black glutinous grain (sorghum) 3 [?] black grains

(Signature in large characters with finger stamp)

The properties recorded here are rather miscellaneous: clothes, tools, butter, grains, etc. The scope of 'properties' in the more common household records mentioned earlier in the book is limited to land, livestock and larger possessions. But the level of detailedness in this manuscript suggests that it must have some special purposes.

Amongst the grain accounts excavated in Khara-Khoto, there is a special manuscript fragment, labelled Инв. No. 4761-10. It is written in cursive

17 TN: Tangut: 拜 [tsow], could be a transliteration of the Chinese 胙, meat for sacrificial rituals, or 酢, vinegar. 


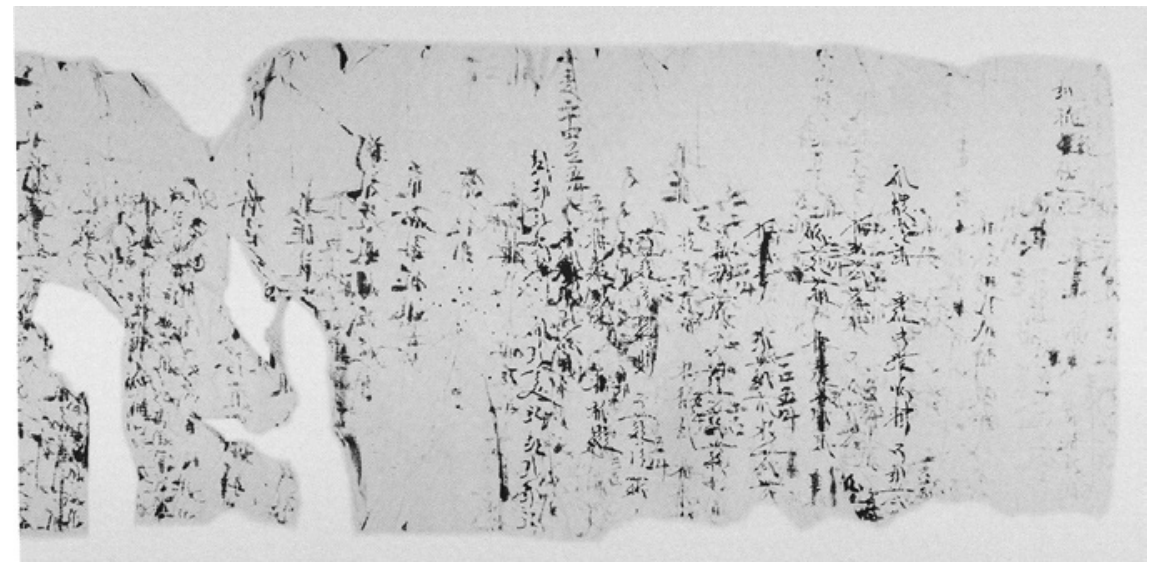

FIGURE 67 Инв. No. 4761-10: Tangut-Chinese bilingual grain account (1)

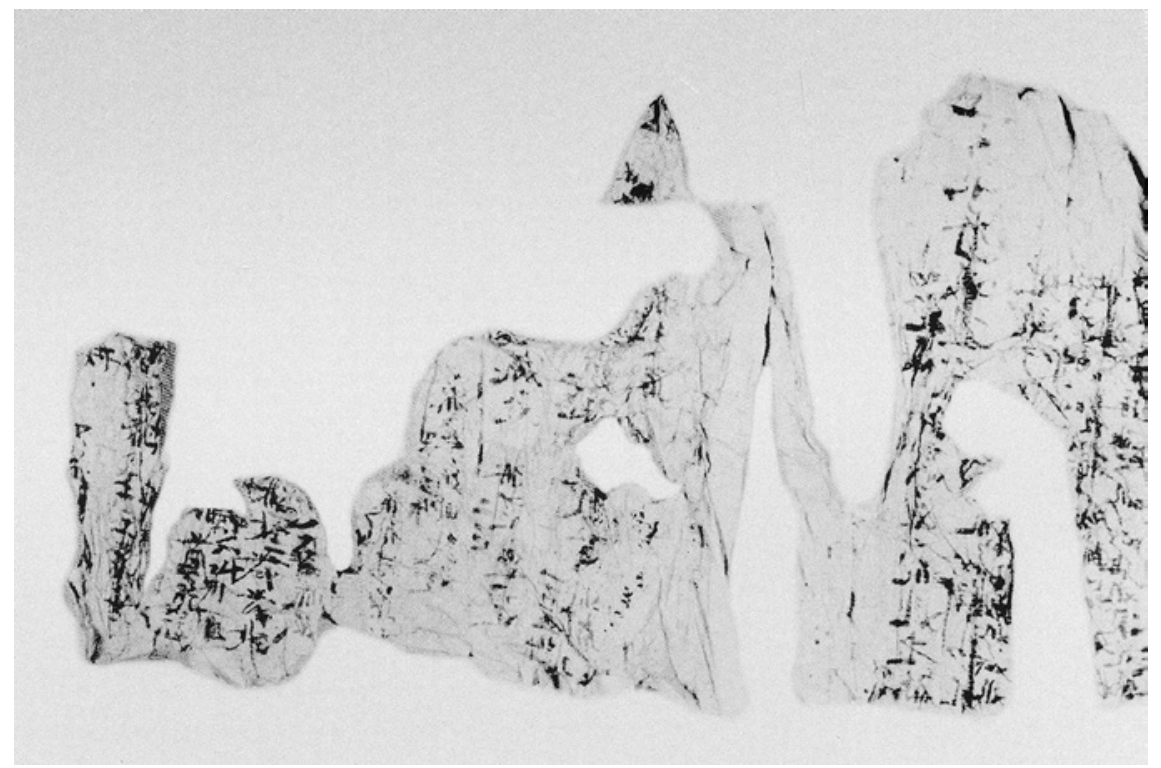

FIGURE 68 Инв. No. 4761-10: Tangut-Chinese bilingual grain account (2)

Tangut ( 56 lines, with edits and erasures), with Chinese notations by the side or on top of important numbers. The manuscript itself is handwritten on a $19 \mathrm{~cm} \times 70.8 \mathrm{~cm}$ piece of hemp paper. ${ }^{18}$

This blurry and fragmented manuscript is difficult to read and interpret, but not without bits of writings still eligible. For example, one finds some Chinese 


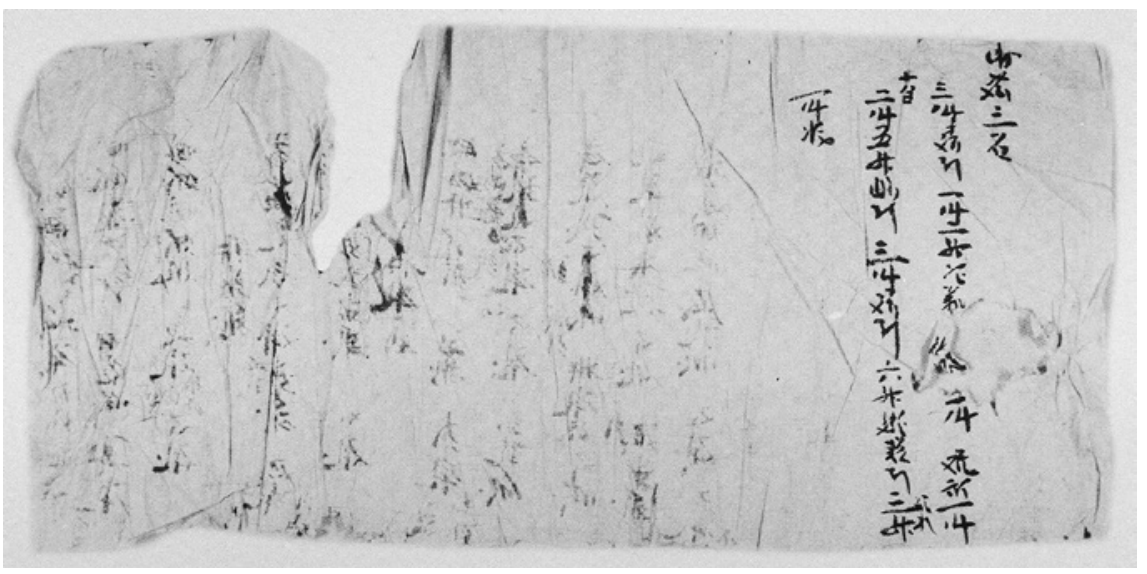

FIGURE 69 Инв. No. 4761-7V: Tangut-Chinese bilingual account

characters added to the side of Tangut text such as " 3 dou," " 1 dan 5 dou," " 5 dou" and "wheat 24 dan 5 dou," etc.

In addition, there is a very special bilingual grain account, Russian manuscript Инв. No. $4761-7 \mathrm{~V}$. Written on the back page of a livestock account, the hemp-paper manuscript $(17.8 \mathrm{~cm} \times 39.5 \mathrm{~cm})$ suffers damages at both of its ends. ${ }^{19}$ The first of its 5 lines reads, "Ajian (a person's name) 3 dan." Lines 2, 4 and 5 indicate the names and quantities of the goods. The numbers are rendered in Han Chinese characters; for example, "three dou," "one dou \& two sheng," "[?] dou," and "one dou" in line 1; "two dou \& five sheng," "three dou," "three dou," "six sheng," and "three sheng" in line 4; and "one dou" in line 5. The types of goods and materials are written in Tangut characters, but most remain unclear in their meaning. One character in the last line appears to mean 'liquor.' In line 3 , there are Chinese notes in smaller font for "day eighteen." These accounts of goods and materials provide us with an invaluable source whence to learn the names of commodities in Tangut social life. With the excavation of these manuscripts, the long-time constraints on our glimpse into the private lives of the Tanguts now give way to a much more promising outlook on the productions and consumptions in the ordinary lives of the Tanguts. This is the first step toward reconstructing a holistic picture of the Tangut social experience.

In brief, the Khara-Khoto accounts of grains and goods compiled by local governments and agencies are large in sum and diverse in kind. They reveal much information on aspects of the Tangut economy that have seldom entered the historiographical conversation in Tangutology before they were 
discovered and deciphered. Some of these records have been identified as statistics on grain provisions supplied to soldiers by the unit of liu in the army. Others document the duties of grain transportation assigned to the local populace. All of them add new materials to our analysis of the Tangut society by providing new angles to consider the Tangut economy.

The statistical accounts also reveal the nomenclatures of goods, products and commodities in common use in Western Xia-iconic and typical but hitherto unknown to historians. Such examples include the technical distinction between 'Fan cloths' and 'Han cloths,' terminology which implies the existence of a Tangut textile industry prior to Dangxiang entry to the Central Plains. It also shows that after the Tanguts established paramountcy in what is today the north-western region of China, Tangut cloths remained unreplaced and continued to be in use alongside the finer Chinese products. This evidence completely changes the once prevalent speculation that the Tanguts boasted no textile industry of their own. 